\title{
SOIL PROPERTIES ASSOCIATED WITH THE INVASIVE NYPA FRUTICANS WURMB AND NATIVE MANGROVE PLANTS IN IBENO, AKWA IBOM STATE, NIGERIA
}

${ }^{*}$ Akpan, Utibe Emmanuel; ${ }^{2}$ Obafemi, Andrew Adesola and ${ }^{3}$ Tanee, Franklin. B.G.

\author{
${ }^{1}$ Institute of Natural Resources and, Environment and Sustainable Development, \\ University of Port Harcourt, Port Harcourt, Nigeria
}

${ }^{2}$ Department of Geography and Environmental Management, Faculty of Social Sciences, University of Port Harcourt, Port Harcourt, Nigeria

${ }^{3}$ Department of Plant Science and Biotechnology, Faculty of Science, University of Port Harcourt, Port Harcourt, Nigeria

*Corresponding Author

DOI: https://doi.org/10.51193/IJAER.2021.7404

\begin{abstract}
The study examined the soil properties associated with the invasive Nypafruticans (INF) and native mangrove plants (NMP) in Ibeno LGA, AkwaIbom, Nigeria. Six 10m x 10m transect were laid randomly in the INF and NMP for the soil samples collection. Soil samples were collected at the depth of $0-15 \mathrm{~m}$ (topsoil) and analysed using the standard methods. Results showed that the soils at both INF and NMP were alkaline (7.13 to 7.14). INF had higher concentration of hydrocarbon $(1315.3 \mathrm{mg} / \mathrm{kg}) \mathrm{NO}_{3}(39.23 \mathrm{mg} / \mathrm{kg})$ and available $\mathrm{P}(2.601 \mathrm{mg} / \mathrm{kg})$ were higher under INF while K (694.23 mg/kg). Na (506.58 mg/kg), Mg (352.8 mg/kg), Mn (37.98 mg/kg) and $\mathrm{Cl}^{-}(11653 \mathrm{mg} / \mathrm{kg})$, and conductivity $(3228.33 \mu \mathrm{S} / \mathrm{cm})$ were significantly higher in soils under NMP than the INF at $\mathrm{p}<0.05$. Therefore, presence of invasive species (Nypafruticans) alters the soil properties of a mangrove ecosystem.
\end{abstract}

Keywords: Soil properties, Invasive, Nypafruticans, Mangrove, Ibeno LGA, Hydrocarbon 
International Journal of Agriculture and Environmental Research

ISSN: 2455-6939

Volume: 07, Issue: 04 "July-August 2021"

\section{INTRODUCTION}

The impacts of alien invasive plants like Nypafruticans on ecosystem in the last decade are becoming worrisome and as well received growing attention. These species alter ecosystems because they differ from natives in eco-physiological traits, such as growth and allocation patterns (Liao et al., 2008). Many alien invasive species have been shown to affect plant and animal communities (Alvarez and Cushman, 2002), ecosystem functioning (Belnap and Philips, 2001), soil properties and nutrient fluxes (Blank and Young, 2002) in the sites they invade.

Nypafruiticans Wurmb. is an invasive alien species to Nigeria from Singapore which was introduced in 1906 to check erosion. Widodo et al., (2019) noted that Nypafruticans is a kind of estuarine plant distributed from Africa, South Asia, Indonesia, to the West Pacific which grows up to $10 \mathrm{~m}$ tall depending on the habitat fertility and produces many propagules which are dispersed with ocean currents. In the Niger Delta, it invades deforested and exposed mudflats and forms dense mono-specific stands which out-compete native mangrove species. The absence of stilt roots, lack of leaf litter and dense structure reduce estuarine habitat and may negatively affect native biodiversity. Biological invasions are considered most concerning threats to biodiversity, loss in terrestrial, fresh water and marine ecosystem (Dam-Roy et al., 2017a). Furthermore, Nipa palm being a tropical plant, halophyte and has evolved mechanism for salt resistance, is found closer to oceans, creeks and estuaries. Nypafruticans is one of major mangrove species, whose habitat is distributed in tropical and subtropical coastal regions, provides important commodity materials to inhabitants from thatching materials, medicinal products (Hamilton and Murphy, 1988) to food sources and bio-ethanol feedstock (Matsui et al., 2011; Matsui and Takahashi, 2016). Nipa palm became an invasive species in Nigeria because it has no natural enemies compared to native mangrove vegetation's which are cut down for firewood, fish stakes, fish traps, board, building, boat paddle, yam stake, fencing, curving etc.

Nigeria native mangrove consists of mostly tree and shrub with prop and pneumatophores roots e.g. Rhizophoreceae with prop (exposed supporting root) and Avicinniaceae with pneumatophores. Native mangrove plays key part in many fish, invertebrate, crustaceans and mollusk species life cycles; mangrove offer organisms a breeding ground (Orimoogunje and Ajibola-James, 2013). Recently, World Wildlife Fund for Nature (WWF) (2020) reported that mangrove forests are extremely productive ecosystem that provides numerous good and services both to the marine environment and people.

The current study was established upon the fact that soil is a life support system which performs multiple functions such as water and nutrient cycling; gas exchange with the atmosphere; supports all forms of terrestrial vegetation (tree, shrubs, grasses, algae, etc (Balestrini, et al., 
International Journal of Agriculture and Environmental Research

ISSN: 2455-6939

Volume: 07, Issue: 04 "July-August 2021"

2015). Jeffery et al., (2010) described soil as a complete community within a given soil system. Soil condition has been recognized as an important factor for mangrove plantation and soil texture and topography have been the basis of species selection (Matsui and Takahashi, 2016). For example, Rhizophora spp. are chosen for muddy areas and Sonneratia spp. for sandy texture. Therefore, mangrove growth can better be explained when soil properties are taken into consideration with topography (Matsui et al., 2008). However, changes in plant community structure may alter near-surface soil properties which could impact root growth, seedling emergence and growth, soil water and nutrient uptake (Hamblin, 1985), or heat capacity (Smith et al. 1987; Sperber et al., 2003). Stubbs Creek Nigeria mangrove soil has been invaded by Nipa palm. Mangroves are considered as one of the major habitats in coastal ecosystem (Albert $e t$ al., 2011). According to Jeffery et al. (2010) invasive plants have a multitude of impact on plant, community through their direct or indirect effect on soil chemistry and ecosystem function.

Several studies have focused on the ecology, distribution, and growth of $N$. fruticans (Teo et al., 2010; Zakaria et al., 2017). For instance, the effects of water properties and soil texture on the growth of a Nypafruticans was studied by Zakaria et al., (2017); also, the effects of light, soil, salinity and disturbances on the growth of many palms have been studied (Tripler et al., 2007). The location of the mangroves, between fresh water and the ocean, is a key site for the deposit of nutrients and other materials (Zakaria et al., 2017). Other studies reported the growth responses of mangroves to salinity and nutrients (Alongi, 2011); and influence of nutrients in sediment with the composition of the mangrove flora (Clarke and Kerrigan, 2000) while Emoyoma et al. (2019) studied the impact of Nipa palm and mangroves forest on benthic macro invertebrate community; but there is limited knowledge on the impact of the species on soil properties. This study therefore, focuses on the effects of $N$. fruticans on soil properties in Ibeno LGA, Akwalbom State, Nigeria.

\section{MATERIALS AND METHODS}

This study was carried out in Ibeno LGA, a riverine community in Akwalbom State. It is bounded to the West by Eastern Obolo LGA, to the North by Onna, EsitEket and Eket LGAs and to the south by the Atlantic Ocean (Figure A). Ibeno LGA has latitudinal extent between $4^{\circ} 30^{\prime}$ $\mathrm{N}$ and $4^{\circ} 45^{\prime} \mathrm{N}$; and longitudinal extent between $7^{\circ} 50^{\prime} \mathrm{E}$ and $8^{\circ} 15^{\prime} \mathrm{E}$. Ibeno occupies the largest coastline of more than $129 \mathrm{~km}$ in Akwalbom State located in the mangrove swamp forest. Mean annual rainfall for this coastal region is high; from 2,000 $\mathrm{mm}$ to $2,500 \mathrm{~mm}$. The mean minimum and maximum temperature are $26{ }^{\circ} \mathrm{C}$ and $30.5{ }^{\circ} \mathrm{C}$ respectively while the mean relative humidity of the area is about $83 \%$ (Werre, 2001). 


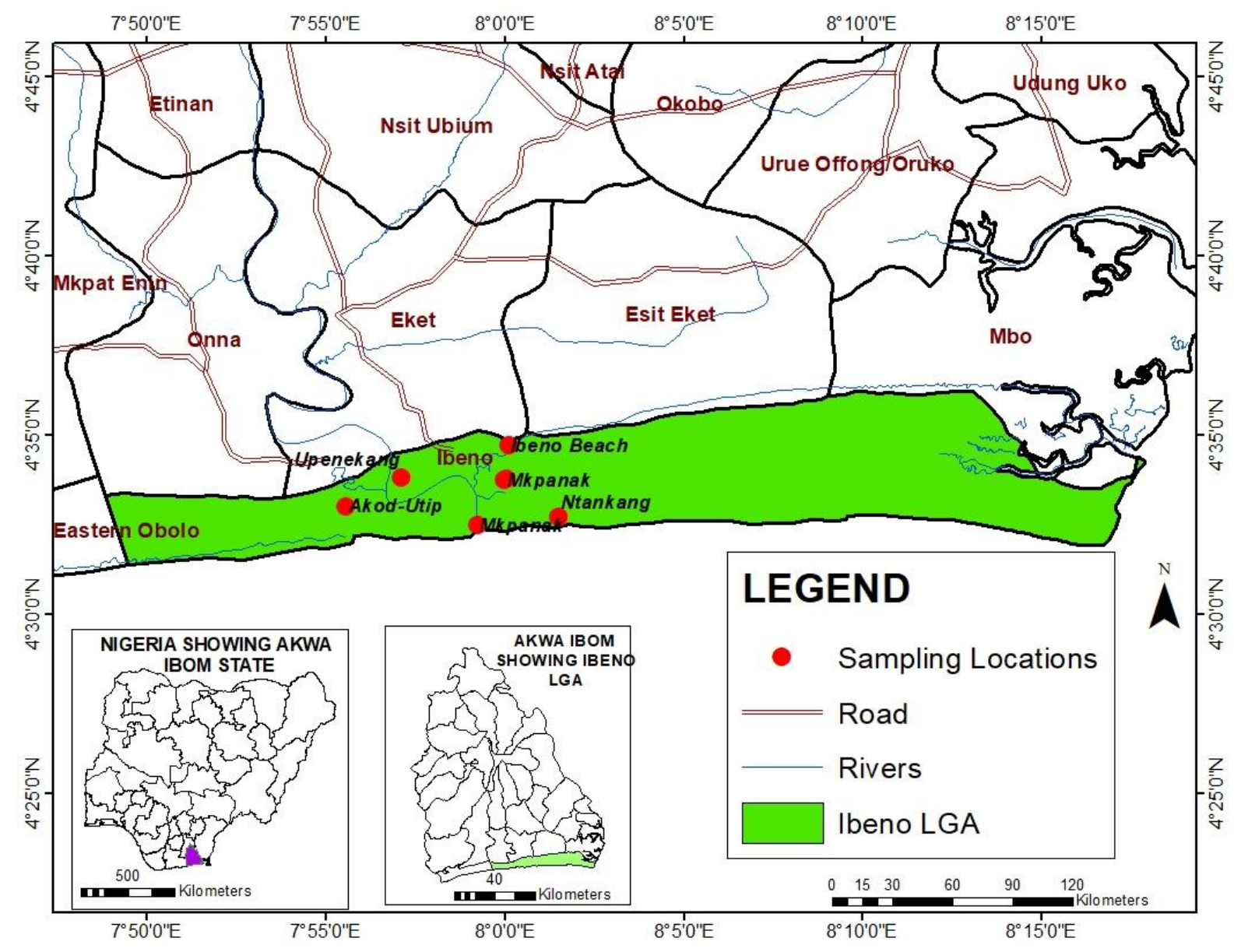

Figure A: Ibeno LGA showing Communities

\section{Soil Samples Collection}

Soil samples were collected from Nipa invasive soil and Nipa non-invasive soil along Akod, Utip River in Ibeno Community. Sampling points were collected from the six $10 \mathrm{~m} \times 10 \mathrm{~m}$ transact that were randomly laid in the study area. Samples were collected into polythene sampling bags with soil auger at a depth of 0-15 cm. All samples were taken in triplicates and properly labeled and thereafter taken to the laboratory in a cooler for analysis of the following parameters; soil $\mathrm{pH}$, conductivity, nitrate, phosphate, potassium, calcium, magnesium, sodium, chloride, total hydrocarbon and manganese. Exchangeable bases which included Calcium $(\mathrm{Ca})$, Potassium (K), and Sodium (Na) were determined using flame photometry (Models PFP7 and PFP7/C), and Magnesium (Mg) using Atomic Absorption Spectrophotometer (Beckman Model $\mathrm{DU})$. Total nitrogen (N) was determined using Kjeldahl steam distillation. Available phosphorus (P) was extracted with Bray and Kurtz solution (0.025M HCL to 0.03MN H4F) using Murphy 
International Journal of Agriculture and Environmental Research

ISSN: 2455-6939

Volume: 07, Issue: 04 "July-August 2021"

and Riley (1962) method. Soil pH was measured potentiometrically in $0.01 \mathrm{M}$ calcium chloride solution using 1:2 soil solution ratio while organic carbon was determined using the method of Walkey and Black (1934). Total hydrocarbon was determined by spectrophotometric method (Method). Descriptive statistics in form of mean and standard errors were used for the data analysis. T-test was employed to separate the means. Results were presented in tables and graphs.

\section{RESULTS AND DISCUSSIONS}

Figures 1 shows the soil $\mathrm{pH}$ at invasive and non-invasive sites were 7.13 and 7.14 respectively. This shows that the $\mathrm{pH}$ in the entire study area was close to neutrality. The value recorded agrees with Komi and Sikoki (2013) and Emoyoma et al., (2019). Studies have shown tropical mangrove forest worldwide and it has been observed that mangrove soils may either be acidic or alkaline. Some researchers found soil pH ranging from 2.87-6.40 (Ukpong, 1997; Moreno and Calderon 2011) while others reported soil pH above 7.0 ranging from 7.4-8.22 (Das et al., 2012; Hossain et al., 2012). Soil pH affect all the physical, biological and chemical soil properties (Brady and Weil, 2016) and the growth of specific organisms, soil microbial biomass and microbial activities. The conductivity of the invasive plot was lower compared to non-invasive plot (Figure 2). Too low EC level indicate low available nutrient and too high EC level indicate excess nutrient in the soil. This shows that non-invasive plants are associated with high EC level which indicates higher soil fertility.

Figure 3 showed that Nipa palm invasive soil has high concentration of hydrocarbon than noninvasive Nipa soil type. Stubbs Creek forest is rich in natural resources both biotic and abiotic. Exxon Mobil and other oil companies are located in Ibeno L.G.A of Akwalbom State the soil is polluted with hydrocarbon. Hydrocarbon concentration from Nipa palm invasive soil plot was very high with mean concentration of $1315.3 \mathrm{mg} / \mathrm{kg}$ compared to non-invasive plot which was $342.65 \mathrm{mg} / \mathrm{kg}$. Hydrocarbon is the main component of crude oil, natural gases and most pesticides. Total hydrocarbon content is used to describe the quality of the measured hydrocarbon impurities present. Ekweozor et al. (2003) had reported 550-900 mg/kg, concentration range along Bonny Estuary. NOAC (2008) recorded 66.30-80.80 mg/kg concentration range along 18 Tebidaba-Brass pipelines at Igbomatoru.

It is also shown that nitrate $\left(\mathrm{NO}_{3}\right)$, and phosphorus $(\mathrm{P})$ which are nutrients were higher in the invasive soil than the non-invasive while potassium $(\mathrm{K})$ was higher in the non-invasive soil. Thus, the non-Nipa palm invasive site is rich in organic matter which improves the soil structure.

The cations namely $\mathrm{Mg}, \mathrm{Ca}$, and $\mathrm{Na}$ were higher in the non-invasive soils than the invasive soil (Figures 7-9). $\mathrm{Mg}, \mathrm{Ca}$ and $\mathrm{Na}$ at invasive soil were $109.4 \mathrm{mg} / \mathrm{kg}, 0.00 \mathrm{mg} / \mathrm{kg}$ and $288.13 \mathrm{mg} / \mathrm{kg}$ 
respectively whereas in non-invasive soils, $\mathrm{Mg}, \mathrm{Ca}$ and $\mathrm{Na}$ were $352.8 \mathrm{mg} / \mathrm{kg}, 18.45 \mathrm{mg} / \mathrm{kg}$ and $506.58 \mathrm{mg} / \mathrm{kg}$. This shows that $\mathrm{Ca}$ at invasive plot was below detectable amount. Plant litter is an important source of organic matter which involves cation exchange capacity (CEC) which is a useful indicator of soil fertility because it shows the soil ability to supply three important nutrients; calcium, magnesium and potassium. Cations are held by negatively charged particles clay and humus called colloids. They act as a storehouse of nutrient for plant roots. On the other hand, Manganese and Chloride were higher in the non-invasive soils (Figures 10-11). The soil in nipa invasive site showed lower concentrations of micro nutrients which included Mn (13.03 $\mathrm{mg} / \mathrm{kg}$ ) and $\mathrm{Cl}(933.3 \mathrm{mg} / \mathrm{kg})$, compared with non-invasive plot in which $\mathrm{Mn}$ was $37.98 \mathrm{mg} / \mathrm{kg}$ and $\mathrm{Cl} 11653 \mathrm{mg} / \mathrm{kg}$. All soil properties were significantly varied between invasive and noninvasive soils except $\mathrm{Ca}$ at $\mathrm{p}<0.05$.

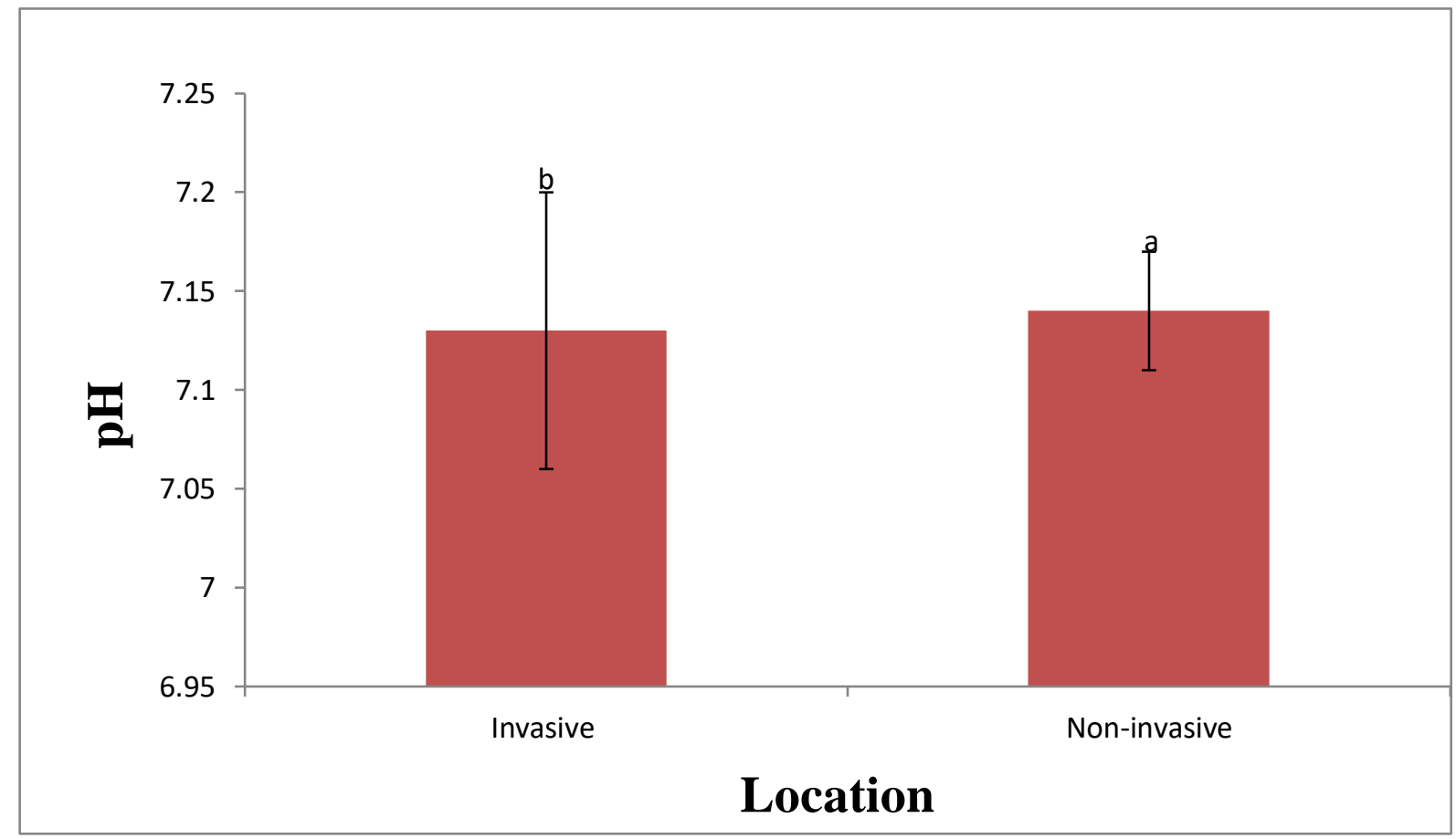

Figure 1: Mean pH in invasive and non-invasive plots with the standard error 


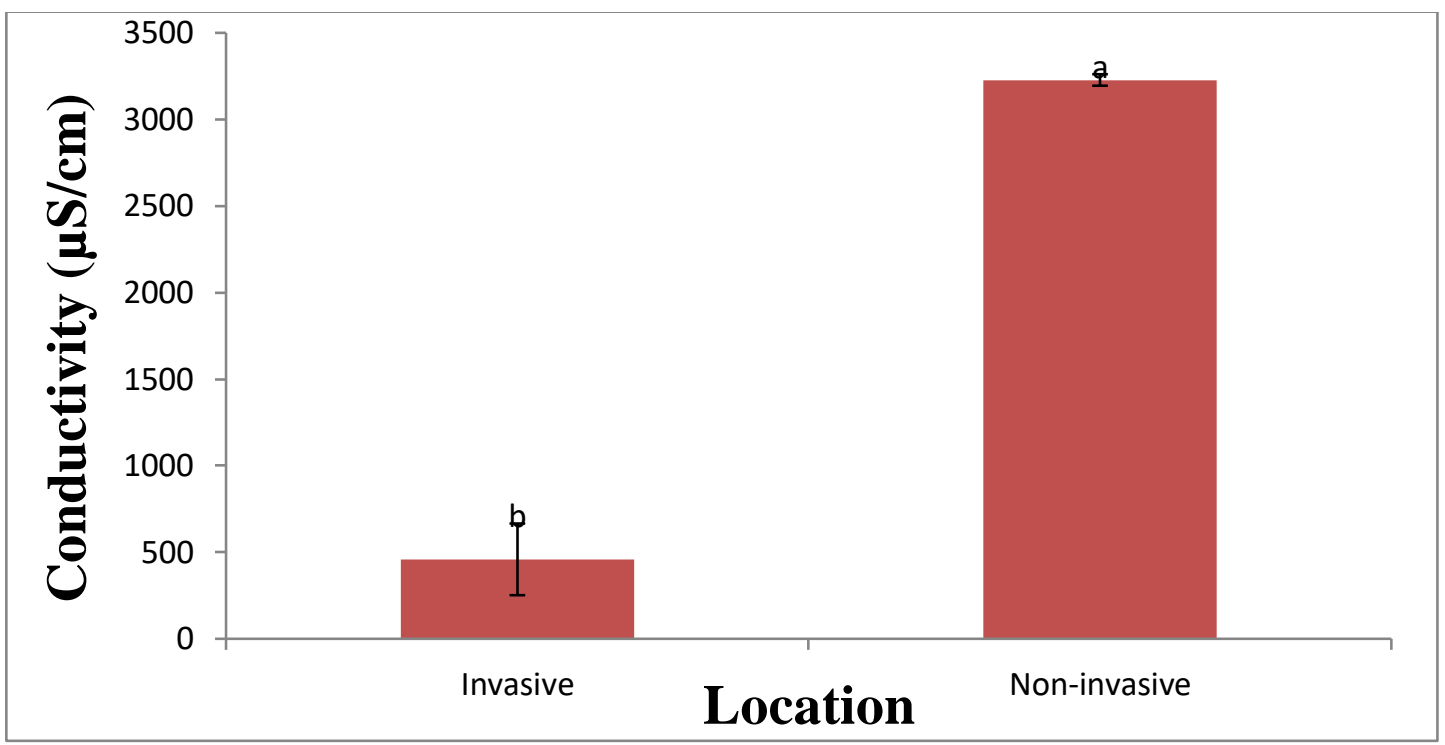

Figure 2: Mean conductivity in invasive and non-invasive plots with the standard error

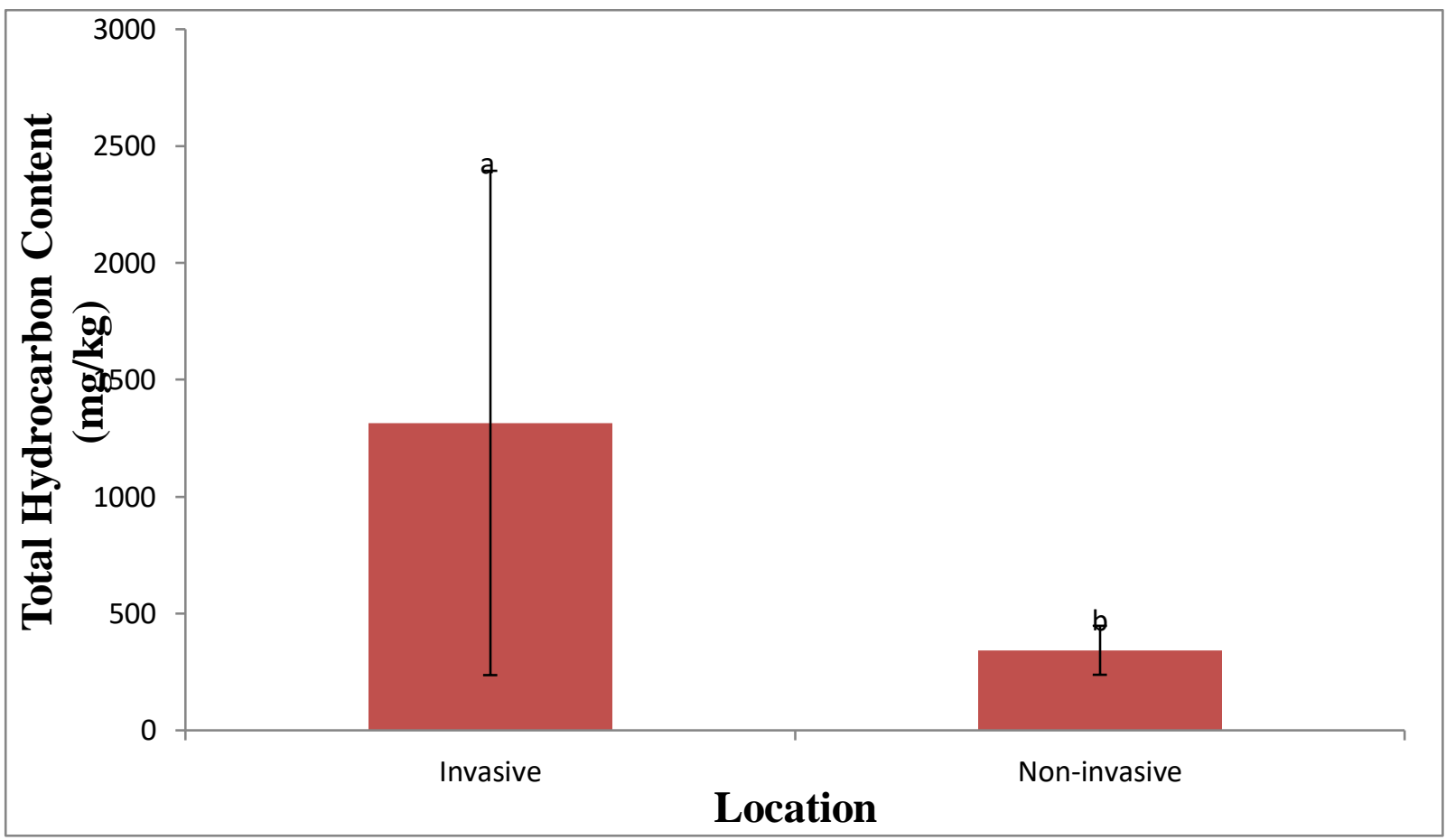

Figure 3: Mean total hydrocarbon in invasive and non-invasive plots with the standard error 


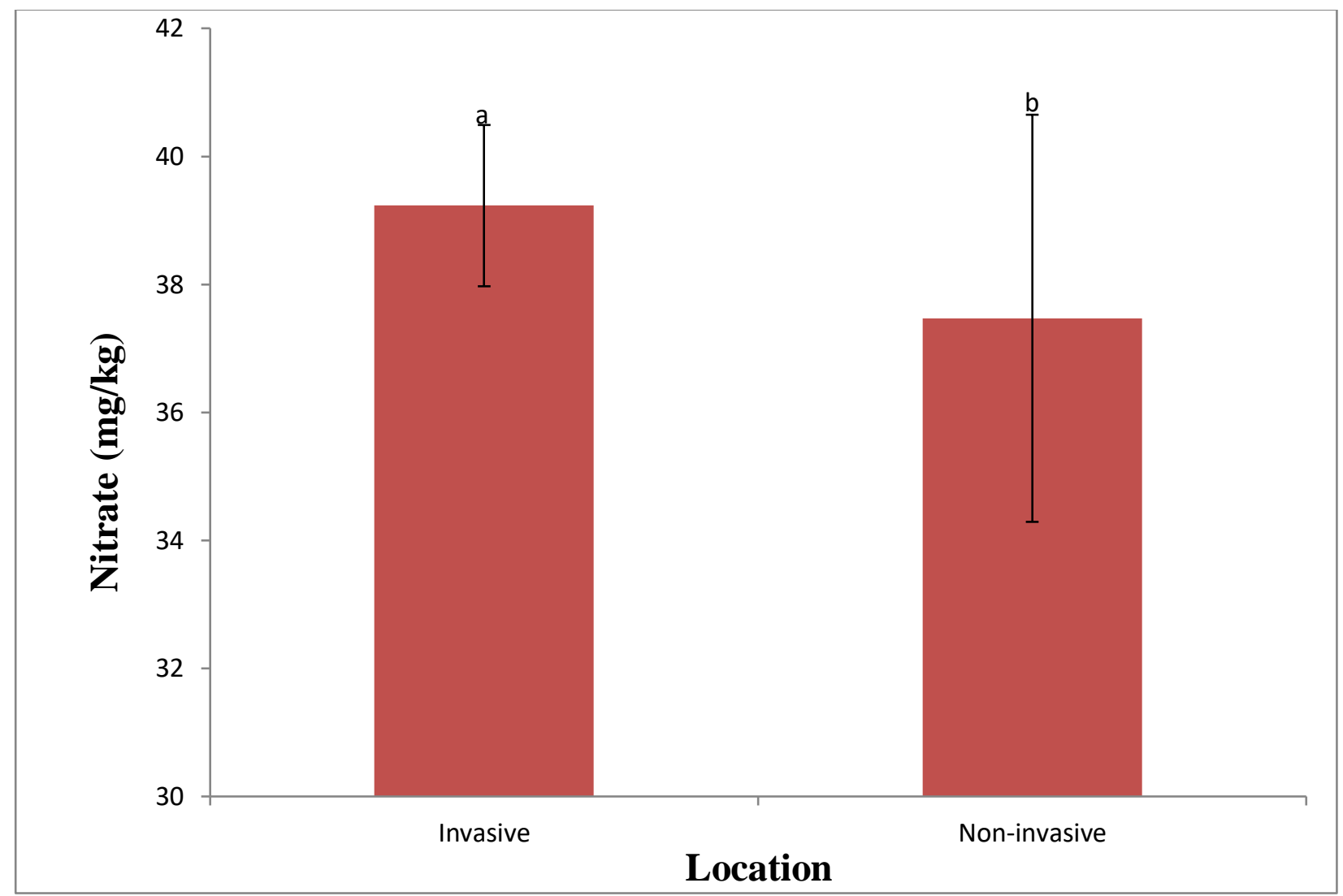

Figure 4: Mean nitrate in invasive and non-invasive plots with the standard error 


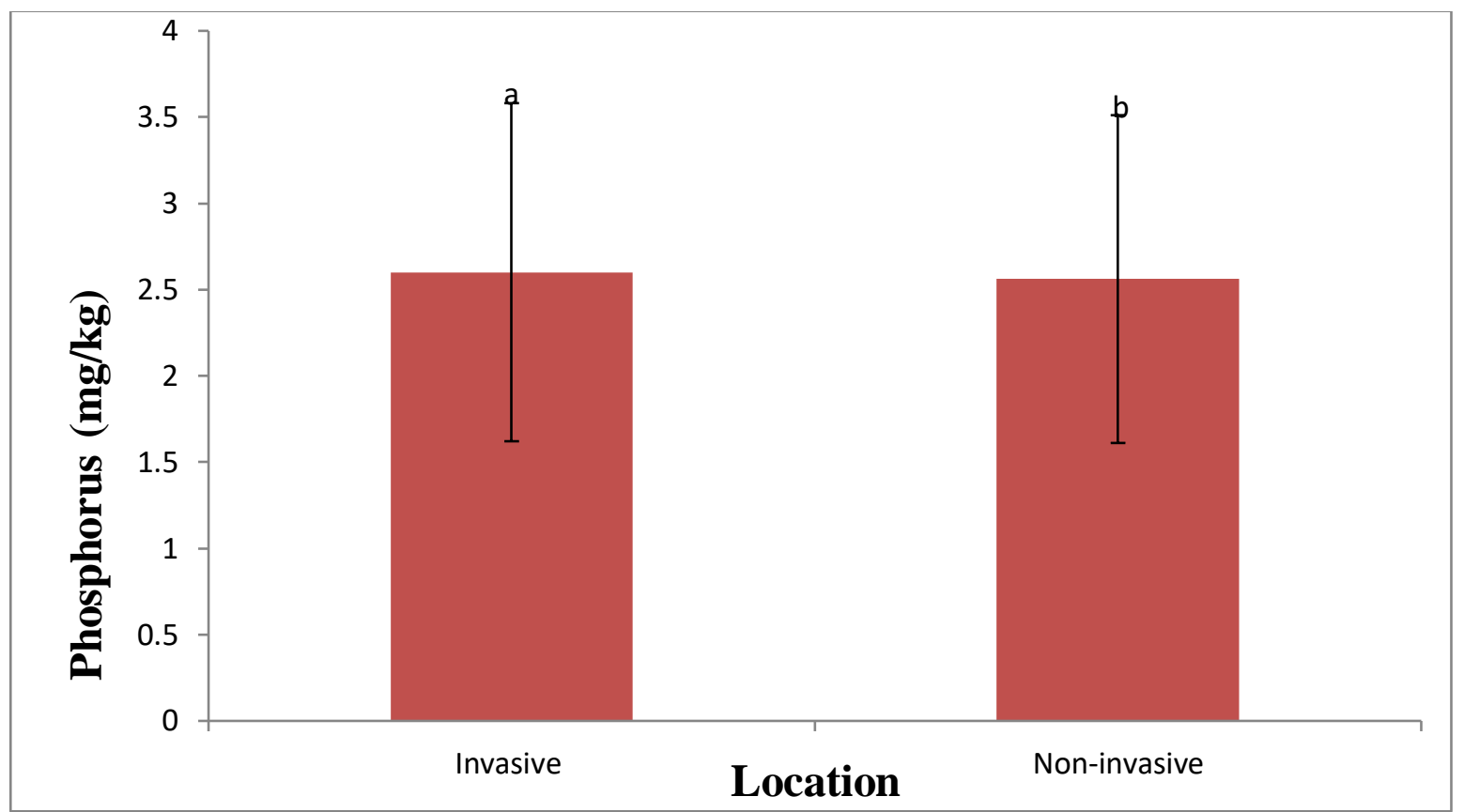

Figure 5: Mean phosphorus in invasive and non-invasive plots with the standard error

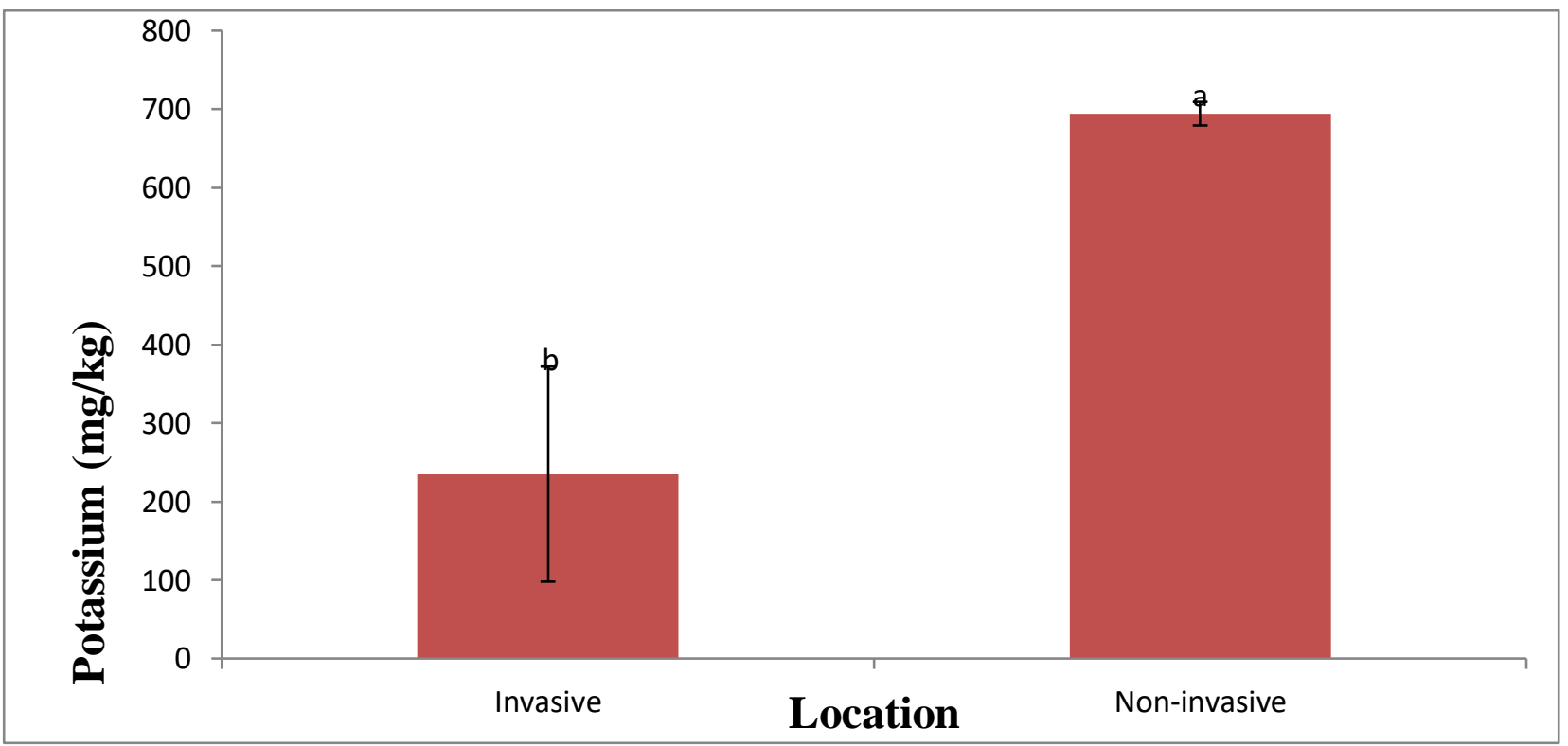

Figure 6: Mean potassium in invasive and non-invasive plots with the standard error 


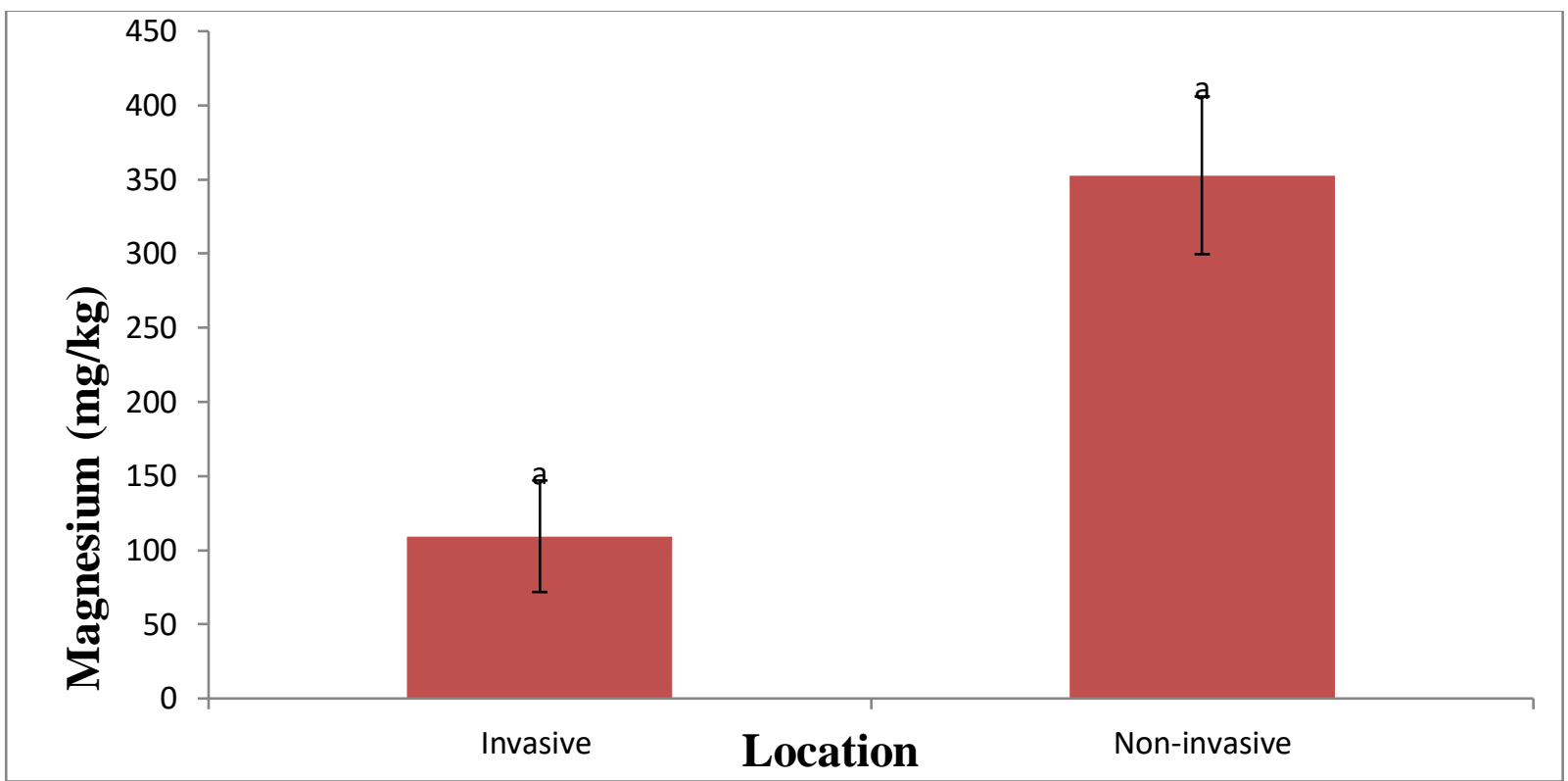

Figure 7: Mean magnesium in invasive and non-invasive plots with the standard error

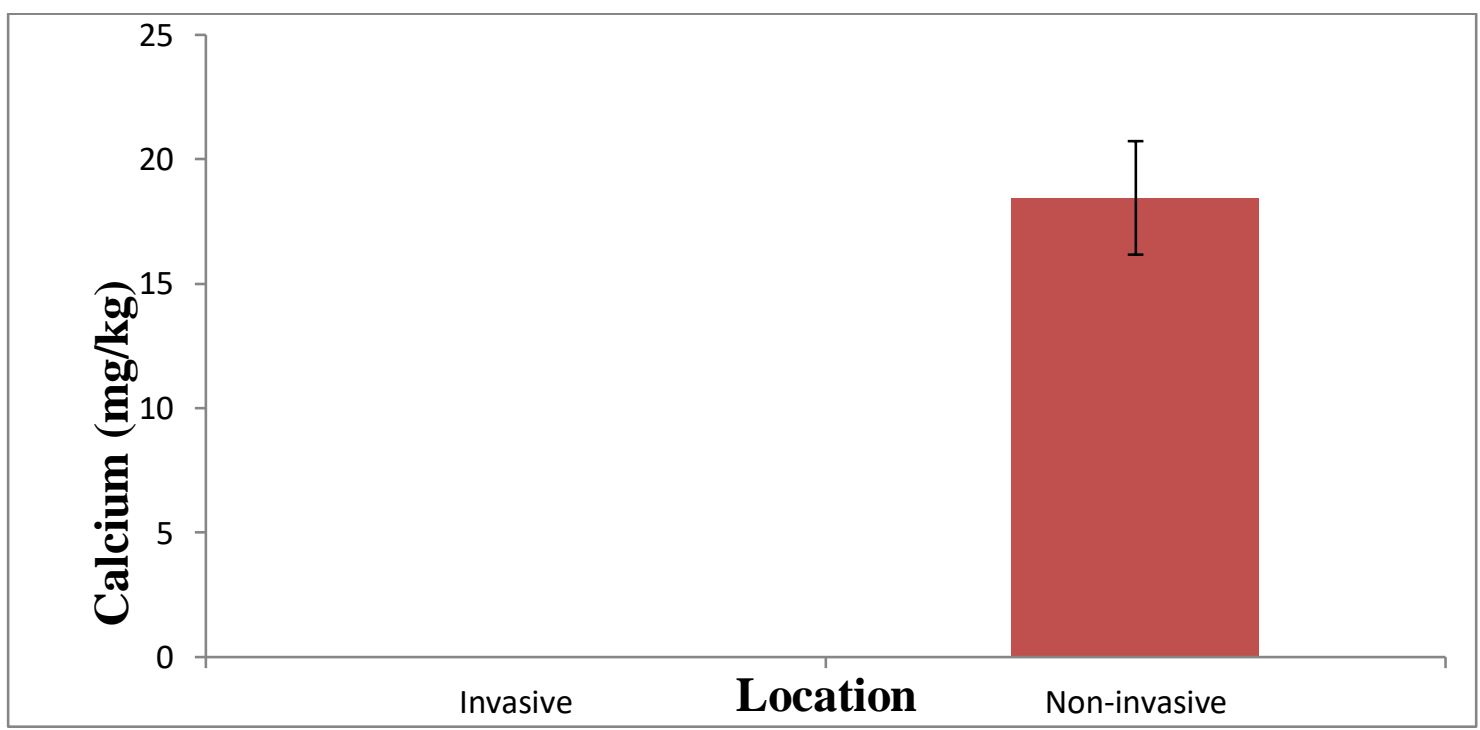

Figure 8: Mean calcium in invasive and non-invasive plots with the standard error 


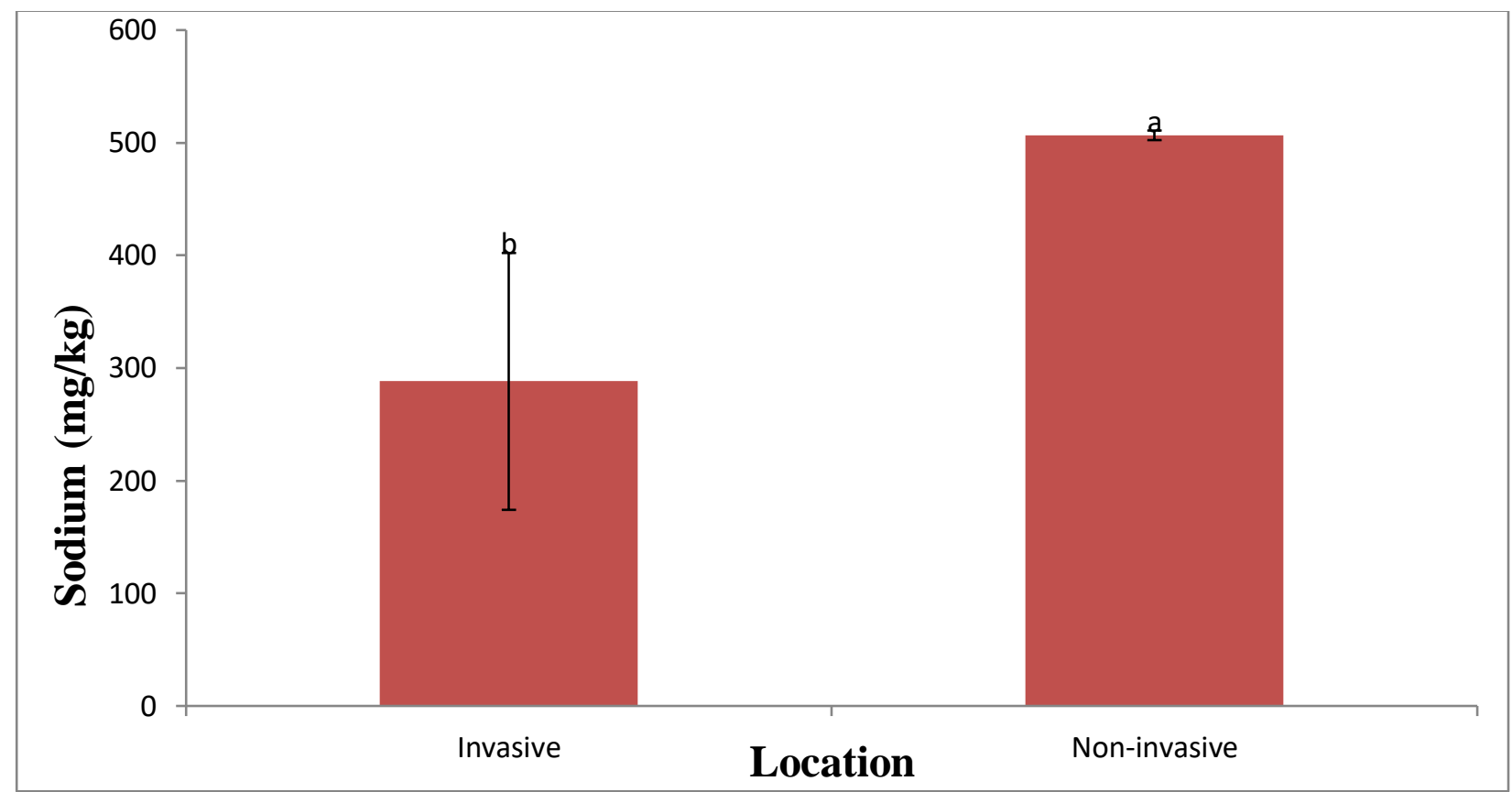

Figure 9: Mean sodium in invasive and non-invasive plots with the standard error

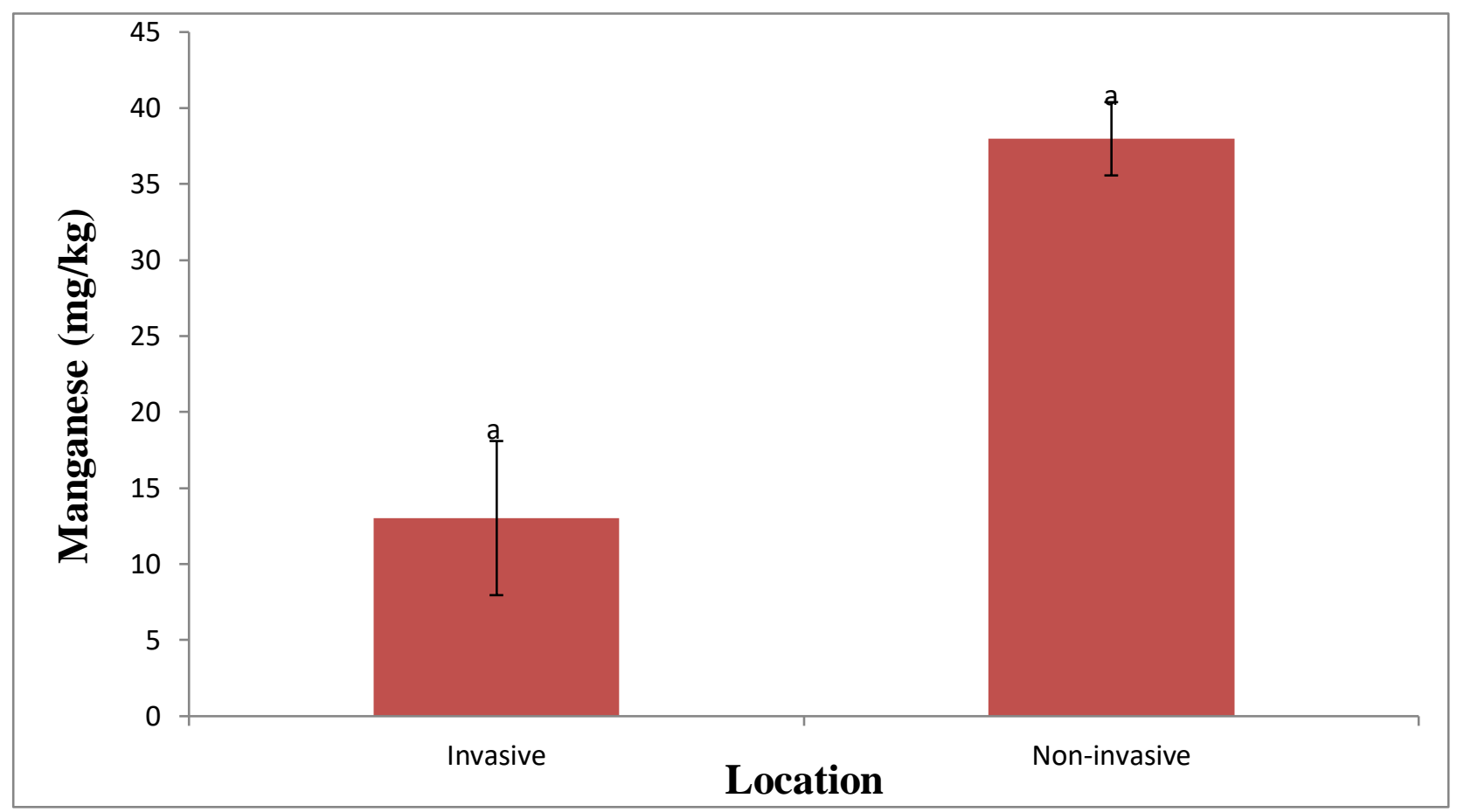

Figure 10: Mean manganese in invasive and non-invasive plots with the standard error 


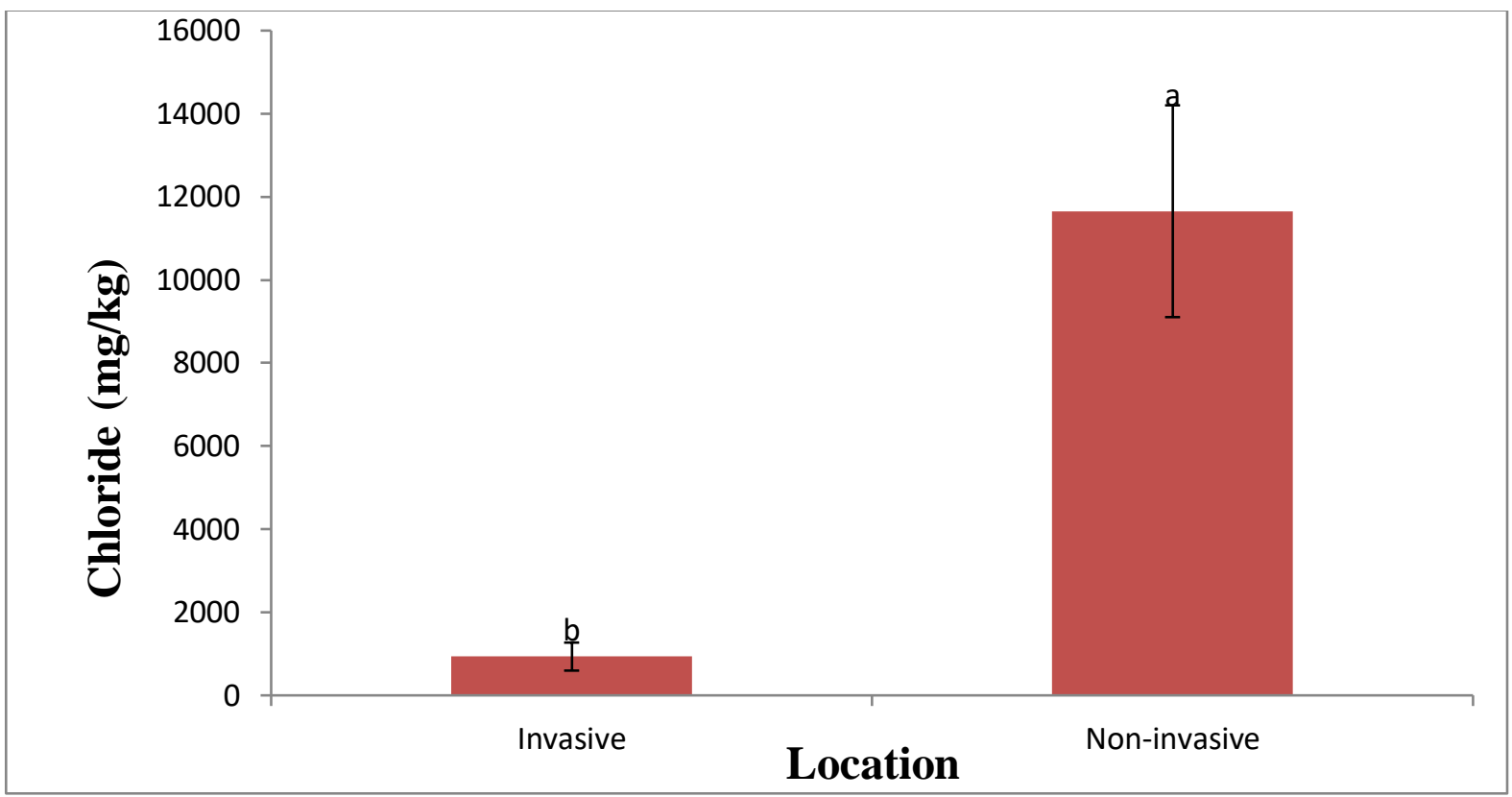

Figure 11: Mean chloride in invasive and non-invasive plots with the standard error

\section{CONCLUSION}

It can be concluded that the conductivity, $\mathrm{K}, \mathrm{Mg}$ and $\mathrm{Na}$ were extremely higher in the noninvasive soils than the Nipa palm invasive plot. In addition, total hydrocarbon was extremely higher under the Nipa palm invasive soils than the non-invasive plot. However, nitrate and $\mathrm{P}$ which build the nutrient level of soils were slightly higher in the invasive soils whereas the micronutrients $(\mathrm{Mn}, \mathrm{Cl})$ were lower in the invasive soil. It therefore showed that invasive Nypafruticans has the potential to alter the soil chemical properties of a mangrove soil, hence control measures of the invasion of Nypafruticans should be put in place as to restore the original nature of the mangrove soil.

\section{REFERENCES}

Albert J.A., Olds, A.D., Albert, S. Cruz-Trinidad, A., and Schward, A.M. (2015): Reaping the reef: provisioning services from coral reefs in Solomon Islands, Marine Policy, 62 :244251.

Alongi, D.M. (2011). Early growth responses of mangroves to different rates of nitrogen and phosphorus supply. J. Exp. Marine Biol. and Ecol., 397(2): 85-93. 
International Journal of Agriculture and Environmental Research

ISSN: 2455-6939

Volume: 07, Issue: 04 "July-August 2021"

Alvarez M.E. and Cushman J.H. (2002). Community-level consequences of a plant invasion: effects on three habitats in coastal California. Ecol. Appl., 12:1434-144

Balestrini, R., Lumini, E., Borriello, R.,andBianciotto, V. (2015). Plant-Soil Biota Interactions. In Paul E. Soil Microbiology, Ecology and Biochemistry, $4^{\text {th }}$ Edition, Chapter 11, Published by Academic Press Elsevier: 311-338.

Bardgett, R.D. and Wardle, D.A. (2010). Above ground-belowground linkages. Biotic interactions, ecosystem processes and global change. Oxford University Press, Oxford, UK.

Belnap J. and Philips S.L. (2001). Soil biota in an ungrazed grassland: response to annual grass (Bromustectorum) invasion. Ecol. Appl. 11:1261-1275

Blank R.R., and Young J.A. (2002) Influence of the invasive crucifer, Lepidiumlatifolium, on soil properties and elemental cycling. Soil Sci, 167:821-829

Brady, N. C. and Weil R. R., (2016): The nature and properties of soils, $15^{\text {th }}$ edition. http://lccn.loc.gov/201600856

Clarke, P.J. and Kerrigan. R.A. (2000). Do forest gaps influence the population structure and species composition of mangrove stands in Northern Australia? Biotropica, 32(4a): 642652.

Dam Roy S, Krishnan P., Patro S., Grinson G., Velmurugan, A., Sankar K. R. and Ramachandran P. (2017a). Wetlands of Small Island Nations in South Asia vis-à-vis the Mainland and Island Groups in India: Status and Conservation Strategies. In: Prusty B., Chandra R., and Azeez P. (eds) Wetland Science. Springer, New Delhi: Pp 31-48

Dam Roy, S., Krishnan, P., Velmurugan, A., Anand, A., Grinson, G., Sankar, K.R., and Swarnam, T.P. (2017b): Wetlands of tropical islands under changing climate: A case from nicobar group of islands. In: Anjan Kumar, B., Rachna Chandra, P., Azeez, P.A. (Eds.), Wetland Science Perspectives from South Asia. Springer, India: Pp 205-224.

Das, S., M. De, D. Ganguly, T.K. Maiti, A. Mukherjee, T.K. Jana and T.K. De, (2012). Depth integrated microbial community and physico-chemical properties in mangrove soil of Sundarban, India. Adv. Microbiol., 2: 234-240.

Ekweozor I., Dambo W B, and Daka E.R. (2003). Zinc and Cadmium in Crassostreagasar from the lower Bonny Estuary, Nigeria. J. Niger. Environ. Soc.1: 31-40 
International Journal of Agriculture and Environmental Research

ISSN: 2455-6939

Volume: 07, Issue: 04 "July-August 2021"

Ekwere M.E. (2016): Effects of Gas Flaring on the Lung Health of Ibeno Community Residents, Ibeno LGA, Akwalbom State, South-South Nigeria. A Dissertation submitted to the National Post Graduate Medical College of Nigeria in Partial Fulfilment of the requirements for the Award of the Fellowship of the Medical College in Internal Medicine Certification (Pulmonology). 78P

Emoyoma U.O., Numbere A.O. and Woke G.N. (2019): Impact of Nipa palm (Nypafruticans Wurmb) and Mangroves Forest on Benthic Macro Invertebrate Community in Andoni River, Nigeria. International Letters of Natural Sciences, 77:51-62.

Hamblin A. P. (1985): The influence of soil structure on water movement, crop root growth, and water uptake. Adv. Agron. 38, 95-158.

Hamilton, L. S., and Murphy, D. H. (1988). Use and management of nipa palm (Nipafruticans, Arecaceae): a review. Economic Botany, 42(2):206-213.

Hossain, M.Z., C.B. Aziz and M.L. Saha, (2012). Relationships between soil physico-chemical properties and total viable bacterial counts in Sunderban mangrove forests, Bangladesh. Dhaka Univ. J. Biol. Sci., 21: 169-175.

Jeffery, S., Gardi, C., Jones, A., Montanarella, L., Marmo, L., Miko, L., Ritz, K., Peres, G. R€ombke, J., W., Van der Putten, (2010). European Atlas of Soil Biodiversity. European Commis-sion. Publications Office of the European Union, Luxembourg.

Komi, G.W. and Sikoki, F.D. (2013): Physico-chemical Characteristics of the Andoni River and its potentials for production of the Giant Tiger Prawn (Penaeusmonodon) in Nigeria. Journal of Natural Sciences Research, 3(12) (2013) 83

Liao C, Peng R, Luo Y, Zhou X, Wu X, Fang C, Chen J, and Li B. (2008): Altered ecosystem carbon and nitrogen cycles by plant invasion: a meta-analysis. New Phytol 177:706-714

Matsui N. and Takahashi F. (2016): Determination of Soil-Related Factors Controlling Initial Nipa (Nypafruticans Wurmb.) Growth in an Abandoned Shrimp Pond. Environment and Natural Resources Research, 6(1);125-132.

Matsui, N., Bamroongrugsa, N., Morimune, K., Miyasaka, H., and Okimori, Y. (2011). Nipa palm: A potential alternative source for bioethanol. Research Paper 14th Mangrove National Seminar. 319-324. 
International Journal of Agriculture and Environmental Research

ISSN: 2455-6939

Volume: 07, Issue: 04 "July-August 2021"

Matsui, N., Suekuni, J., Havanond, S., Nishimiya, A., Yanai, J., and Kosaki, T. (2008). Determination of soil-related factors controlling initial mangrove (Rhizophoraapiculata BL.) growth in an abandoned shrimp pond. Soil Sci Plant Nutr, 54, 301-309.

Moreno, A.N.M. and Calderon, J.H.M. (2011). Quantification of organic matter and physicalchemical characterization of mangrove soil at Hooker Bay, San Andres Island-Colombia. Proceedings of the Global Conference on Global Warming, July 11-14, 2011, Lisbon, Portugal:1-7.

Murphy, J., and Riley, J.P. (1962). A mordified single solution for determination of phosphate in natural waters. Anal. Chem. Acta, 27, 31-36.

NAOC, 2005. Nigerian Agip Oil Company: Oil Spill Statistics from 1994-2005

Orimoogunje O.O.I. and Ajibola-James, O. (2013). Mangrove Ecosystem Recovery and Restoration from Oil Spill in the Niger Delta: The GIS Perspective. Geoinformatics and Geostatistics: An Overview.

Smith P L, Redente E F and Hooper E 1987 Soil organic matter. In Reclaiming Mine Soils and Overburden in the Western United States, Analytical Parameters and Procedures. Eds. Williams R D and Schuman G. E. Soil Conservation Society of America, Ankeny, 185214

Sperber T.D., Wraith J.M. and Olson B.E. (2003): Soil physical properties associated with the invasive spotted knapweed and native grasses are similar. Plant and Soil, 252: 241-249

Teo S, Ang W, Lok A, Kurukulasuriya B, and Tan H (2010) The status and distribution of the nipah palm, Nypafruticans Wurmb (Arecaceae), in Singapore. Nat Singapore 3:45-52

Tripler,E., Ben-Gal, A., Shani, U., (2007).Consequence of salinity and excess boron on growth, evapotranspiration and ion uptake in date palm (Phoenix dactylifera L., cv, Medjool). Plant Soil, 297,147-155

Ukpong, I.E. (1997). Vegetation and its relation to soil nutrient and salinity in the Calabar mangrove swamp, Nigeria. Mangroves Salt Marshes, 1: 211-218.

Wardle, D.A., Bardgett, R.D., Klironomos, J.N., Seta la“, H., van der Putten, W.H., and Wall, D.H. (2004). Ecological linkages between aboveground and below ground biota. $\underline{\text { Science }}$ 304:1629-1633. 
Walkey, A. and Black, C.A. (1934): "An examination of the degrjareff method of determining soil organic matter and a proposed modification of chromic acid titration method", Soil Science, 37:29-38.

Werre, J. L. R. (2001). In review. Cross-Niger transition forests (AT0106). Report to the World Wildlife Fund.

Widodo P., Sukarsa W., Herawati, H.A., Hidayah, T., and Chasanah, E.P. (2019): Distribution and Characteristics of Nipa palm (Nypafruticans Wurmb.) in Southern Part of Cilacap Regency. International Conference of Mangroves and Its Related Ecosystems 2019. 6P

WWF (2020): Mangroves and coastal ecosystems. Available at https://www.iucn.org/theme/marine-and-polar/our-work/climate-change-andocean/mangroves-and-coastal-ecosystems. Accessed on 4/3/2021

Zakaria R. M., Aslezaeim N. and Sofawi A.B. (2017): Effects of Water Properties and Soil Texture on the Growth of a Mangrove Palm; Nypafruticans on Carey Island, Malaysia. Pak. J. Bot., 49(1): 33-39. 